\title{
Turizm Rehberliği Lisansüstü Eğitiminde Alan Dışı Öğrenci Alımı Paradoksu
}

The Paradox of Students' Acceptance from Different Programs for Tourism Guidance Postgraduate Education

\author{
Caner ÜNAL*, Özlem GÜZEL**, Muhammedali YAŞAR***, Fatma Nur KELEŞ**** \\ *(Sorumlu Yazar) Dr. Öğr. Üyesi, Antalya Bilim Üniversitesi, Turizm Fakültesi, Turizm Işletmeciliği Bölümü, Çıplaklı Mah. Akdeniz Bulvarı No: 290 A, 07190, \\ Döşemealtı, Antalya. \\ E-posta: caner.unal@antalya.edu.tr
}

ORCID: 0000-0002-2591-3389

**Doç. Dr., Akdeniz Üniversitesi Turizm Fakültesi, Dumlupınar Bulvarı, 07058, Kampüs, Antalya.

E-posta: ozlemmguzel@hotmail.com

ORCID: 0000-0003-0081-3530

***Yüksek Lisans Öğrencisi, Akdeniz Üniversitesi Sosyal Bilimler Enstitüsü, 07058, Antalya.

E-posta: muhammedaliclay.96@gmail.com

ORCID: 0000-0002-1504-882X

****Yüksek Lisans Öğrencisi, Akdeniz Üniversitesi Sosyal Bilimler Enstitüsü, 07058, Antalya.

E-posta: fnkeles@gmail.com

ORCID: 0000-0003-1862-5669

MAKALE BILGILERI

Makale işlem bilgileri:

Gönderilme tarihi:2 Mart 2021

Düzeltme: 2 Haziran 2021

Kabul: 22 Temmuz 2021

Anahtar sözcükler: Turist rehberliği,

Turist rehberliği eğitimi, Turist rehberi meslek yönetmeliği, Madde 23, Tezlitezsiz yüksek lisans.

\section{ARTICLE INFO}

Article history:

Submitted: 2 March 2021

Resubmitted: 2 June 2021

Accepted: 22 July 2021

Key words: Tourist guide, Tourist guide training, Tourist guide vocational regulation, Article 23, Master with thesis and non-thesis.

\section{$\ddot{O Z Z}$}

Turist Rehberliği Mesleği Yönetmeliği'nde yer alan Madde 23 “üniversitelerin turist/turizm rehberliği bölümlerinin ön lisans, lisans veya yüksek lisans programlarından mezun olan ve yabancı dil yeterliliğine sahip bulunanlara" mesleğe kabul edilmenin yolunu açmaktadır. Bu maddeden yola çıkarak bu çalıșmanın amacı yüksek lisans programlarına alan dışı öğrencilerin kabulüne ilişkin eleştirel bir bakış açısı sergilemektir. Söz konusu yönetmeliğin sunduğu haklar gereği seçilen örneklemin duruma ilişkin bakış açısını değerlendirmek üzere nitel araștırma yöntemi tercih edilmiștir. Amaçlı örnekleme yöntemlerinden kartopu örnekleme tekniği benimsenerek ve yarı yapılandırılmış görüşme formu kullanılarak turizm rehberliği lisans ve lisansüstü öğrencileri, turist/turizm rehberliği akademisyenleri ve turist rehberlerinden elde edilen veriler, betimsel analize tabi tutulmuştur. Madde 23'e yönelik görüşler kapsamında ortaya çıkan temalar şunlardır: eğitim eksikliği; eğitim programının yetersizliği; mesleki dejenerasyon; rehberlere yönelik psikolojik etki; rehberlik bölümü öğrencilerine yönelik psikolojik etkisi; mesleki aidiyet eksikliği; mesleki yetersizlik; meslek istihdamına etkisi; lisansüstü programına yönelik eleştiriler; eğitim veren akademisyenler; eğitim programı müfredatı; müfredat içerik planlama; lisansüstü alım koşulları; program iyileştirme ve öğrencilere yönelik entegrasyondur. Bu temalar, söz konusu maddeye ilişkin makro bakış açısı sunarken, lisansüstü rehberlik eğitimine ilişkin görüşler ve önerilerde tanımlanmıştır.

\begin{abstract}
The Article 23 which takes place in Tourist Guide Profession Regulation states; "undergraduate, bachelor and master degree graduates of the department of Tourist Guide program and who is acquired with sufficient foreign language" opens a way to be approved for the profession. On the basis of Article 23, the aim of this study is to present a critical point of view concerning with the approvement of non-field students in Tourist Guide master degree program. A qualitative approach was preferred to evaluate the perspective of the chosen sample in accordance with the rights provided by respective regulation. Snowball sampling technique which one of the purposive sampling methods has been adopted. The data obtained by applying a semi-structured interview form upon tourism guide undergraduate and postgraduate students, academicians, and tourist guides, were subjected to descriptive analysis. The themes emerging within the scope of the opinions regarding Article 23 are: lack of education; inadequacy of education program; degeneration of profession; psychological effect on tourist guides; psychological effect on students of tourist guide department; deficiency of professional belongingness; professional insufficiency; effect on professional employment; criticism of postgraduate program; teaching academics; curriculum of education program; planning of curriculum content; postgraduate recruitment requirements; program improvement, and integration for students. While these themes present a macro perspective regarding the article in question, the themes also portray the opinions and recommendations related to postgraduate tourism guide education.
\end{abstract}




\section{Giriș}

Turist Rehberliği mesleği insanların seyahat etmeye başladıkları anlardan itibaren ortaya çıkmış olup, turizm faaliyetlerinin gelişimine paralel olarak mesleki bir nitelik kazanmıştır. Resmi Gazetede 26.12.2014 tarihinde 29217 sayılı yayımlanarak yürürlüğe giren "Turist Rehberliği Meslek Yönetmeliği" ile birlikte de turist rehberliği mesleği tüzel bir kişilik elde etmiştir (Güzel 2014: 59). 7/6/2012 tarihli ve 6326 sayılı Turist Rehberliği Meslek Kanunundan dayanağını alan bu yönetmelik, turist rehberliği mesleğine kabule, mesleğin icrasına ve turist rehberliği meslek kuruluşlarının kuruluş ve işleyişine ilişkin usul ve esasları düzenlemektedir. Kanun'a göre turist rehberliği mesleğine; turist rehberliği ile ilgili eğitim veren ön lisans, lisans ve yüksek lisans programlarından mezun kişiler yabancı dil yeterliğini sağlayıp Turist Rehberleri Birliği'nin (TUREB) uygulama gezisini başarmak suretiyle kabul edilmektedirler.

Yönetmelikte 23. Madde "üniversitelerin turist/turizm rehberliği bölümlerinin ön lisans, lisans veya yüksek lisans programlarından mezun olan ve yabancı dil yeterliliğine sahip bulunanlara" mesleğe kabul edilmenin yolunu açmaktadır. Alanyazında yüksek lisans programlarını ele alan tek isim olan Çokişler (2017), turizm rehberliği eğitiminin "Bakanlık, üniversiteler, TUREB ve YÖK" arasındaki koordinasyonsuzluk ve güç çatışması nedeniyle giderek parçalandığını, bu bozuk yapı içinde, bir meslek eğitiminin, bilgi üretmekle yükümlü fakülteler bünyesinde mi, yoksa meslek yüksekokulları içinde mi yürütülmesi gerektiği tartışılmadan, yüksek lisans eğitimine geçildiğinin altını çizerken, bu durumda yükseköğretimin ticarileştiğini belirtmektedir. Gerek sosyal medya platformların da gerekse akademik toplantılarda dile getirilen Yüksek Lisans Programların "geniş yelpazedeki alan dışı ve/veya Kanunda vurgulanan düzeyde dil şartı aranmadan $(75 / C)$ " öğrencilerinin kabul edilmesi paradoksunun somut boyutlarının tartışılması için gerçekleştirilen bu araştırma keşifsel bir bakış açısı sunmaktadır. Bu bağlamda bu çalışmanın amacı, Madde 23 ile ilgili tezli ve tezsiz yüksek lisans programlarından mezun olan kişilere turist rehberi olma hakkı sunmasına dair turizm paydaşlarının görüşlerini tespit etmektir.

\section{ALANYAZIN TARAMASI}

\section{Turist Rehberliği Mesleği ve Mesleki Eğitimin Önemi}

Profesyonel turist rehberi, "belirli bir tur programı çerçevesinde yerli ve yabancı turistlere yol gösteren, destinasyon noktaları hakkında yararlı bilgileri doğru ve öz biçimde aktaran, tur süreci boyunca danışmanlık hizmeti sunan, ziyaretçiev sahibi arasında iletişim aracı olan ve ülke ve bölge tanıtımında sosyo-kültür elçiliği rolüne sahip kişilerdir" (McDonnell 2001: 3; Huang vd. 2010: 6; Köroğlu 2010: 224; Ar 2015: 35). Seyahat edenler gidecekleri destinasyonlara yabanci oldukları için destinasyon hakkında siyasi, coğrafi, ekonomik, tarihi, kültürel ve mitolojik bilgilere sahip güvenilir rehberlere ihtiyaç duymuşlardır (Cohen 1985). Bu denli geniş bir görev yetkisine sahip olan rehberler, sektörde üstlendikleri roller gereği önemli bir eğitim alt yapısına sahip olmalıdır (Güzel vd. 2019). Doğal ve tarihi kültürün temsilcisi olan turist rehberleri iyi bir şekilde seçilerek eğitime tabii tutulmalıdır (Coccossis 2005). Turistlere daha iyi ve kaliteli bir hizmet sunmanın gerekliliği olan eğitim, aynı zamanda turist rehberlerin bilgi ve becerilerini sürekli geliştirmesine ve performanslarının artması içinde gereklidir (Christie ve Mason 2003; Huang vd. 2010; Rabotić 2015; Eker ve Zengin 2016; Kabii vd. 2017). Seyahat acenteleri yöneticileri de rehberlerin iyi eğitilmesi ve yetiştirilmesi konusunun önemli olduğunu belirtmektedir (Çetin ve Yarcan 2017). Çünkü rehberlik tecrübesi öncesinde, destinasyon bilgisinin gelişimi turist rehberliği eğitiminden geçmektedir (McDonnell 2001). Modern turist rehberliğinin gerçek misyonu ve önemi, güçlü ve zengin kültürel tecrübe birikimiyle (mitoloji, alegolik edebiyat, tarih, coğrafya vb.) ortaya çıkmaktadır (Cohen 1985: 6).

Dünya genelinde gelişmekte olan ülkelerin turizm eğitimi ve öğretimiyle ilgili öngörülen birtakım eksiklikler vardır. Bunlar şu şekilde s1ralanabilir: eğitim müfredatının yetersizliği, alanında uzman kişilerden tutarlı ve kaliteli eğitim alınmaması, turizmin geleceği hakkında akademik ve uygulama alanındaki taraflarının gerekli 
görüldügünde eleştiri ya da değerlendirme yapabilecekleri ortamlarının olmaması ve eğitimle turizm sektörü arasında koordinasyon eksikliği (Mayaka vd. 2007: 299-300). Değirmencioğlu (2001), rehberlerin ülke, bölge, yöre, tarihi eserler ve değerler hakkında yeterli bilgi sahibi olmalarını gerekliliğin ötesinde bir zorunluluk olarak görürken rehberlerin eğitimini turizm sektöründe biraz daha ayrı bir noktada göstermektedir. Turist rehberliği mesleğinin uluslararası tanınırlığ arttıkça turist rehberliği eğitimi de artık önem kazanmaktadır (Black ve Weiler 2005). Eğitim süreçleri bazı mesleklerde ülkeden ülkeye benzerlik gösterirken farklılıklarda göstermektedir. Diğer meslekler gibi, turist rehberliği mesleğini icra edebilmek için mesleki eğitim süresi gibi önemli olan yeterlilikler ülkeden ülkeye benzerlikler ve farklılıklar bulunmaktadır. Türkiye'deki gibi dört yıllık Turizm Rehberliği lisans programı sürecine benzerlik gösteren Rusya, Ukrayna ve Hong Kong gibi ülkelerde dört veya beş yıllık profesyonel turizm rehberliği eğitimi almak esastır. İngiltere, Yunanistan, Kırgizistan, Azerbaycan, Özbekistan ve KKTC gibi ülkelerde rehber olabilmek için en az iki yıl profesyonel bir eğitim sürecinden geçmek gerekmektedir. Ülkemizdeki eğitim süreci ile kıyaslandığı zaman İskoçya (28 gün), Fransa (12-14 hafta), ABD (17 gün), Japonya (20 saat), Zimbabve (3 ay), Almanya (6-9 ay) ve Birleşik Arap Emirlikleri (10 gün) gibi ülkelerde bu eğitimin çok kısa sürede tamamlandığ 1 görülmektedir. Son olarak, Hırvatistan, Kanada, Çin, Singapur ve Mısır gibi ülkelerde eğitim sürecinin olmadığ saptanmıştır (Tanrısever 2019: 53-54). Ülkemizde Profesyonel Turist Rehberliği Yönetmeliği esaslarınca, 1995 yılına kadar turist rehberliği eğitimi kısa süreli kurslarla, Kültür ve Turizm Bakanlığı tarafından yürütülmekteydi. Zamanla üniversite düzeyinde eğitimin çeşitlendirilmesi ile birlikte üniversiteler de rehberlik programı açmışlar ve konuya akademik boyut kazandırmışlardır (Polat 2001). Üniversitelerin turist rehberliği bölümlerinin ön lisans veya lisans programlarından mezun olanlar yabancı dil yeterliliğine sahip olduktan ve uygulama gezisini başarıyla tamamladıktan sonra gerekli belgeleri tamamlayarak Kültür ve Turizm Bakanlığ1na müracaat edebilmekteydi. Eş zamanlı olarak
Bakanlığın gözetimi ve denetimi altında TÜREB tarafından düzenlenen ülkesel veya bölgesel turist rehberliği sertifika programları düzenlemekteydi. Ancak 26 Aralık 2014'te yayınlanan Turist Rehberliği Meslek Yönetmeliği'nde var olan bir madde üç boyutlu eğitimin saç ayağına bir yenisini daha eklemiştir. Yönetmelikte yer alan Madde 23, tezli ve tezsiz yüksek lisans programlarından mezun olan kişilere rehber olma hakkının kapısını açmıştır. Kanunu'nun yüksek lisans eğitimi ile rehber olma hakkı vermesinin ardından, yüksek lisans programı ilk defa 2014-2015 yılında açılmıştır. Alanyazında yüksek lisans eğitimlerinden sonra rehber olma hakkının adaylara verilmesi "haksız rekabet" ve "fırsat eşitsizliği" olarak nitelendirilirken, turist rehberliği eğitiminin daha parçalı bir hal aldığı eleştirisi yapılmaktadır (Çokişler 2017). Bu noktada bazı üniversitelerin ilgili anabilim dallarında, tezli ve tezsiz yüksek lisansüstü programlarına herhangi bir alan giriş kısıtı ve/veya alt dil baraj şartı getirilmeden açılması durumu, bu yüksek lisans programlarından mezun olan kişilere rehber olmanın kapısını açarken, üniversitelerin turist rehberliği bölümlerindeki ön lisans ve lisans programlarından mezun olan rehber adaylarına yeni rakipler çıkarmaktadır. Bu bağlamda Yönetmelikte yer alan Madde 23'ün geniş bir bakış açısıyla değerlendirilmesi gerekirken, bu araştırmanın temel problemi ortaya çıkmıştır. Bu kapsamda çalışmada "Madde 23 ile ilgili tezli ve tezsiz yüksek lisans programlarından mezun olan kişilere rehber olma hakkı sunmasına ilişkin turizm paydaşlarının görüşleri nelerdir?" şeklinde kurulan problem cümlesine aşağıdaki alt problemler çerçevesinde yanıt aranmiştır:

Alt Problem 1.Turizm paydaşlarının Turist Rehberliği Meslek Yönetmeliği Madde 23 ile ilgili tezli ve tezsiz yüksek lisans programlarından mezun olan kişilere rehber olma hakkı sunmasının, turist rehberliği eğitiminin nitelikleri, verimliliği ve gerekliliğine dair görüşleri nelerdir?

Alt Problem 2. Turizm paydaşlarının lisansüstü seviyesinde verilen turist rehberliği eğitiminin ilişkin görüşleri nelerdir? 
Alt Problem 3.Turizm paydaşlarının lisansüstü seviyesinde verilen turist rehberliği eğitiminin planlanması ve düzenlenmesine ilişkin görüşleri nelerdir?

\section{ARAŞTIRMA YÖNTEMI}

Farkında olunan ancak ayrıntılı ve derinlemesine bir anlayışa sahip olunan olgulara odaklanan fenomenolojik yaklaşımın (Yıldırım ve Şimşek 2013), temelini bireysel deneyimler oluşturmaktadır (Creswell 2016). Turizm paydaşlarının madde 23 ile ilgili deneyimlerini ortaya koymaya çalışan bu fenomenolojik çalışmada, bu süreçte yaşanan deneyimler, algılar, yönelimler ve durumlar derinlemesine incelenebilir. Böylelikle fenomene ilişkin deneyimler sorgulanarak deneyimlerindeki anlamın özünün anlaşılmasına çalışılmıştır. "Madde 23" üzerine yapılacak bir araştırma turizm paydaşların rehberlik mesleğinin gelişimini tüm dinamikleriyle ilgili öyküleri ortaya koyacak zengin bir veriye ihtiyaç bulunmaktadır. İhtiyaç duyulan veri zenginliğini nicel yöntemlerle sağlanabilmesi oldukça güçtür. Bu bakımdan çalışmada "Madde 23" konusunun geniş bir kavrayışa ihtiyaç duyması ve bu nedenle en uygun yöntemin sonuçlara ulaşmayı sağlayan nitel bir teknik olan olgu bilim/fenomenoloji analizi olduğuna karar verilmiştir.

\section{Örneklem, Veri Toplama Aracı ve Veri Analizi}

Çalışmaya amaçlı örnekleme yöntemi (kartopu örneklemesi) kapsamında turizm rehberliği öğrencileri, turist/turizm rehberliği akademisyenleri ve turist rehberleri araştırmaya dahil edilmiştir. Lisans ve lisansüstü öğrencileri, eğitimin parçası ve deneyim aktörleri olduğu için; turist rehberleri, lisansüstü eğitimin mesleki istihdam üzerine etkisi gözlemledikleri için; turist/turizm rehberliği akademisyenleri ise uzman görüşüne ihtiyaç duyulması ve eğitim aktörleri olmaları nedeniyle çalışmaya dahil edilmişlerdir. Ayrıca, çalışmaya seçilen 13 kişi rehberlik çalışma kartına, tecrübesine (üç yıldan otuz altı yıla) ve çeşitli rehberlik uzmanlık alanlarına (örn. bölge, kültür, gastronomi ve inanç turları) sahiptir. Araştırmada, yarı yapılandırılmış görüşme formu kullanılmıştır. Bu bağlamda görüşme (yüz yüze ve telefon ile) ve e-mülakat tercih edilmiştir. Gerçekleştirilen görüşmeler, 30-40 dakika arasında sürmüştür. Görüşmelerin tamamı, 01.11.2019 ile 25.12.2019 tarihleri arasında gönüllülük esasına dayalı olarak gerçekleştirilmiştir.

Fenomenolojik çalışmalarda Polkinghorne'nin (1989) aktardığı üzere görüşmeler için uygun katılımcı sayısı "beş ile yirmi beş arasında değişmektedir" (Creswell 2016: 81). Araştırma kapsamında toplamda on yedi katılımcı ile görüşülmüştür. Veri doygunluğu sağlandığında görüşmeler tamamlanmıştır. Çalışma kapsamındaki katılımcı sayısı, nitel desende tasarlanan diğer turist rehberliği çalışmaları (Wong ve Wang 2009; Mak vd. 2011; Wong ve Lee 2012; Tsaur ve Lin 2014) ile benzerlik taşımaktadır. Katılımcılar, K1, K2, K3 şeklinde kodlanmıştır.

Görüşmeler ses kayıt cihazı yoluyla kayıt altına alınmış olan sözel veri dikkatli biçimde deşifre edilmiştir. Deşifre edilen ve hazır hale getirilen veriler betimsel analiz tekniğine tabi tutulmuştur. Betimleyici fenomenolojide veri analizi, önemli açıklamalar ve temalar üzerine kurgulanmaktadır (Creswell 2016). Bu bağlamda katılımcıların fenomene ilişkin önemli ifadeleri belirlenmiştir. Akabinde ortak ifadeler gruplandırılmıştır. Bunun sonucunda ortak ifadeler belli temaları oluşturacak biçimde bölümlendirilmiştir.

\section{Araştırmanın Geçerliği ve Güvenirliği}

Nitel araştırmalarda "geçerlik" bilimsel bulguların doğruluğunu yansıtırken, "güvenirlik" ise bilimsel bulguların tekrarlanabilirliğini ifade etmektedir (Yıldırım ve Şimşek 2013). Fenomenolojik yaklaşım gösteren bu araştırmada geçerlik ve güvenirlik kriterlerinin sağlanması için çeşitli adımlar takip edilmiştir. Yarı yapılandırılmış görüşme formu ilgili alan yazının detaylı incelenmesi sonucunda oluşturulmuş ve temaların kendi aralarındaki ilişki ve tema-kod ilişkisi sağlanarak bütünlük sağlanmıştır. Görüşme esnasında katılımcılara kaydedilen bilgilerin sadece bilimsel amaçlı kullanılacağı belirtilerek, bilgilerin gizliliği konusunda katılımcı izin formu aracıl1ğıyla katılımcılarla güven ilişkisi kurulmuştur. Direkt alıntılar şeklinde sunulan verilere herhangi bir yorum eklenmeyerek araştırmanın iç ge- 
çerliğini (inandırıcılığını) artırılması sağlanmıştır. Çalışmanın dış geçerliğin (aktarılabilirliğin) sağlanması için görüşme sorularının hazırlanmaS1, araştırmanın modeli, çalışma grubu ve özellikleri, veri toplama araçları, veri toplama süreci, verilerin çözümlenmesi ve analizi olmak üzere araştırma sürecine yönelik ayrıntılı bilgilere yer verilmiştir. Araştırmada amaçlı örnekleme yöntemlerinden kartopu örnekleme tekniği benimsenmiştir. Çalışmanın iç güvenirliğini (tutarlılığını) sağlamak açısından veriler alanında uzman bir akademisyen tarafından analiz edilmiş, elde edilen sonuçlar karşılaştırıldıktan sonra tutarlılık oranı hesaplanmıştır. Bu çalışmada Kappa katsayısının 0,78 olarak belirlenmiş olması kodlamalar arasında önemli düzeyde bir uyumun olduğunu göstermiştir (Landis ve Koch 1977).

\section{ARAŞTIRMANIN BULGULARI}

Elde edilen bulgular, paydaşlar bağlamında üç kısımda irdelenmiştir. Öncelikle turizm rehberliği eğitimi alan lisans/lisansüstü öğrenciler, turizm rehberliği alanındaki akademisyenler ve profesyonel turist rehberleri bağlamında ayrı ayrı görüşmeler yapılmıştır. Tablo 1 , görüşme yapılan paydaşlara ilişkin demografik bilgileri sunmaktadır.

Alt Problem 1 Çözümlemesi: Verilerden elde edilen bulgular sekiz tema altında toplanmıştır (Tablo 2). Bu temalar; eğitim eksikliği, eğitim programının yetersizliği, mesleki dejenerasyon, rehberlere yönelik psikolojik etkisi, rehberlik bölümü öğrencilerine yönelik psikolojik etkisi, mesleki aidiyet eksikliği, mesleki yetersizlik ile meslek istihdamına etkisi olarak tanımlanmıştır (Şekil 1).

Eğitim eksikliği temasında katılımcıların çoğu, teorik ve uygulamalı ders eksikliklerinin ortaya çıkacağını önemle belirtmiştir, yüksek lisans programından mezun olan kişinin temel eğitim bakımından zayıf olacağını, multidisiplinler arası bakış açısına sahip olunmayacağını, turizm disiplinine hakim olunamayacağını ve uzmanlaşma da eksiklik meydana geleceğini vurgulamaktadırlar. Katılımcıların büyük çoğunluğu alan-dışından tezli ve tezsiz lisansüstü eğitim programına alınan kişilerin Turizm Rehberliği lisans programı mezunu olan alan-içi kişilere göre alacakları eğitim programının yetersiz olacağını vurgulamışlardır. Ayrıca, eğitim programının k1sa olacağını ve eğitim seviyesinde eşitsizlik olacağını belirtmektedirler.

Mesleki dejenarasyon teması kapsamında, katılımcılar Madde 23'ün uygulanmasının mesleki etik açısından uygun bir durum olmayacağını, ülke/meslek imajına zarar verme, mesleki dejenerasyon durumu ile karşılaşılacağını ve turist rehberliği mesleğinin ek iş olarak görülmesine neden olacağını vurgulamışlardır. Rehberlere yönelik psikolojik etki teması kapsamında, katılımcılar alan-dışı kişilerin Madde 23 ile rehber olma hakk1 elde etmelerinin turist rehberlerinin motivasyonunu düşüreceğini ifade etmiştir. Ayrıca, meslek aidiyet duygusunun gelişemeyeceği de vurgulanmıştır. Katılımcılar mevcut öğrencilerin motivasyonunun kırılacağını vurgulamıştır. Ayrıca, öğrencilerin eğitime yönelik idealist bakış açılarının kaybolacağı belirtilmiştir. Diğer taraftan "mesleğe yönelik güveninin kaybedileceği", "gelecek kaygisısın oluşacă̆ı", "meslek değiştirme eğiliminin artacağı" ve "öğrencilerin özlük haklarının gasp edileceği" katılımcılar tarafından kodlanmıştır. Öğrencilerin ve rehberlerin üzerinde oluşacak olan psikolojik etkiyi şu cümle ile vurgulamışlardır:

\footnotetext{
“Öğrenciler kendilerine haksızlık yapıldığının gayet bilincinde. Bir tarafta dört sene boyunca ağır bir tarih- mitoloji-din müfredatında dirsek çürüten öğrenciler varken diğer tarafta bir sene - iki dönem üstelik rehber hocaları bile olmadan yüksek lisans eğitimini tamamlayıp çalışma kartı alan bireyler..." K12
}

Mesleki aidiyet eksikliği teması altında yer alan kodlara bakıldığında "sorumluluk bilincinin gelişmemesi" ön plana çıkmıştır. Bunun yanı sıra, katılımcılar tarafından "bilinçsiz rehberlerin yetiştirilmesi" ve "mesleğin itibarsızlaşması" da vurgulamıştır. Katılımcılar tarafından eleştirilen mesleki yetersizlik temasında, dört yıllık lisans eğitimi ile karşılaştırıldığında kısa süren lisansüstü eğitimin tamamlanması durumunda çoğunluğu rehberlere yeterli niteliğin kazandırılamayacağ 1 , rehberlerin yeterli donanıma sahip olunmayacağı ve bazıları ise kalitesiz hizmet veren rehberlerin sahaya gireceği konularına değinilmiştir. 
Tablo 1. Katılımcıların Demografik ve Mesleki Özellikleri

\begin{tabular}{|c|c|c|c|c|c|c|c|}
\hline Kod & Meslek/Öğrenci & Cinsiyet & Yaş & $\begin{array}{c}\text { Eğitim/TR } \\
\text { Belgesini } \\
\text { Alma } \\
\text { Eğitimi }\end{array}$ & $\begin{array}{l}\text { Rehberlik } \\
\text { Tecrübesi }\end{array}$ & $\begin{array}{l}\text { Rehberlik } \\
\text { Dil(ler)i }\end{array}$ & $\begin{array}{c}\text { Rehberlik Bölgesi ve } \\
\text { Uzmanlığı }\end{array}$ \\
\hline K1 & Lisans öğrencisi & K & 19 & - & - & - & - \\
\hline $\mathrm{K} 2$ & Lisans öğrencisi & E & 21 & - & - & - & - \\
\hline K3 & $\begin{array}{c}\text { Doktora } \\
\text { öğrencisi ve TR }\end{array}$ & $E$ & 35 & Lisans & $8 \mathrm{yll}$ & İngilizce & $\begin{array}{c}\text { Bölgesel: İç Anadolu ve } \\
\text { Doğu Karadeniz }\end{array}$ \\
\hline K4 & $\begin{array}{c}\text { Doktora } \\
\text { öğrencisi ve TR }\end{array}$ & $\mathrm{E}$ & 36 & Lisans & 3 yıl & İngilizce & $\begin{array}{l}\text { Bölgesel: Marmara, İç } \\
\text { Anadolu ve Ege }\end{array}$ \\
\hline K5 & Lisans öğrencisi & K & 21 & - & - & - & - \\
\hline K6 & $\begin{array}{c}\text { Doktora } \\
\text { öğrencisi ve TR }\end{array}$ & $\mathrm{K}$ & 33 & Lisans & 8 yıl & İngilizce & Bölgesel: Ege \\
\hline K7 & $\begin{array}{c}\text { Akademisyen ve } \\
\text { TR }\end{array}$ & $\mathrm{K}$ & 30 & $\begin{array}{l}\text { Doktora- } \\
\text { Lisans }\end{array}$ & 9 yıl & İngilizce & Ülkesel: Kapadokya \\
\hline K8 & $\begin{array}{c}\text { Akademisyen ve } \\
\text { TR }\end{array}$ & K & 34 & $\begin{array}{l}\text { Doktora- } \\
\text { Lisans }\end{array}$ & 9 yıl & İngilizce & Ülkesel: GAP \\
\hline K9 & $\begin{array}{c}\text { Akademisyen ve } \\
\text { TR }\end{array}$ & $E$ & 43 & $\begin{array}{l}\text { Doktora- } \\
\text { Lisans }\end{array}$ & 10 yıl & İngilizce & Ülkesel: Kapadokya \\
\hline K10 & $\begin{array}{c}\text { Akademisyen ve } \\
\text { TR }\end{array}$ & K & 34 & $\begin{array}{l}\text { Doktora- } \\
\text { Lisans }\end{array}$ & 5 yıl & İngilizce & $\begin{array}{l}\text { Ülkesel: Güney Doğu } \\
\text { Anadolu ve Ege Bölgesi }\end{array}$ \\
\hline K11 & Akademisyen & K & 36 & Doktora & - & - & - \\
\hline $\mathrm{K} 12$ & $\begin{array}{c}\text { Akademisyen ve } \\
\text { TR }\end{array}$ & $\mathrm{E}$ & 33 & $\begin{array}{l}\text { Doktora- } \\
\text { Lisans }\end{array}$ & $7 \mathrm{yll}$ & İngilizce & $\begin{array}{c}\text { Ülkesel: Karadeniz ve } \\
\text { Marmara }\end{array}$ \\
\hline K13 & $\mathrm{TR}$ & $E$ & 81 & $\begin{array}{c}\text { Bakanlık } \\
\text { Kursu }\end{array}$ & 36 yıl & $\begin{array}{l}\text { İngilizce- } \\
\text { Japonca }\end{array}$ & Ülkesel: Kültür turları \\
\hline K14 & $\mathrm{TR}$ & $\mathrm{K}$ & 35 & Ön Lisans & $12 \mathrm{yıl}$ & İngilizce & $\begin{array}{c}\text { Ülkesel: Kültür ve yayla } \\
\text { turları }\end{array}$ \\
\hline K15 & $\mathrm{TR}$ & K & 43 & Ön Lisans & $14 \mathrm{yıl}$ & İtalyanca & Ülkesel: Kültür turları \\
\hline K16 & $\begin{array}{c}\text { TR-Seyahat } \\
\text { Acentesi } \\
\text { Yöneticisi }\end{array}$ & $E$ & 41 & $\begin{array}{l}\text { Bakanlık } \\
\text { Kursu }\end{array}$ & $10 \mathrm{yıl}$ & Rusça & $\begin{array}{c}\text { Ülkesel: Kültür ve inanç } \\
\text { turları }\end{array}$ \\
\hline K17 & $\mathrm{TR}$ & K & 36 & Lisans & $8 \mathrm{yll}$ & İngilizce & $\begin{array}{l}\text { Ülkesel: Kültür ve } \\
\text { gastronomi turları }\end{array}$ \\
\hline
\end{tabular}

Madde 23'ün mesleki istihdam üzerine etkisi kapsamında, katılımcılar büyük çoğunluğu rehber enflasyonu durumuna dikkat çekmiştir. Mevcut rehberlerin ise işsiz kalacağı hemen hemen bütün katılımcılar tarafından kodlanmıştır.
Ayrıca, haksız rekabetin ortaya çıkacağı ve tur/ rehber taban fiyatlarının düşeceği gibi önemli endişeler katılımcılar tarafından belirtilmiştir.

Alt Problem 2'ye Yönelik Çözümlemesi: Bulgular kapsamında üç temaya ulaşılmıştır (Tablo 3). Bu 
Tablo 1. Katılımcıların Demografik ve Mesleki Özellikleri

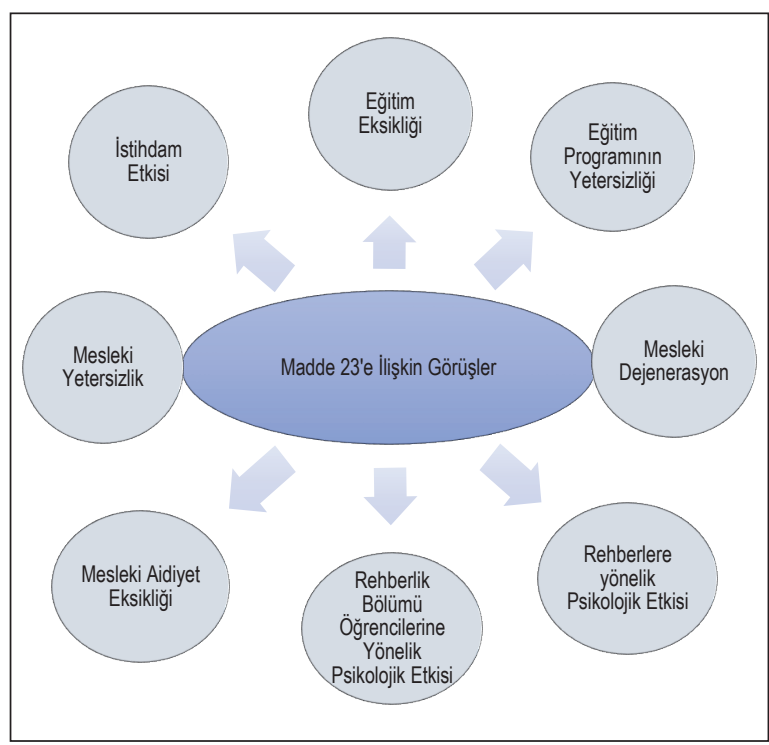

Şekil 1. Madde 23’ün Turizm Rehberliği Eğitiminin Nitelikleri, Verimliliği ve Gerekliliğine Dair Görüşler temalar lisansüstü programına yönelik eleştiriler, eğitim veren akademisyenler ile eğitim programı müfredatı olarak tanımlanmıştır. Üç tema incelendiğinde; "Lisansüstü Programa Yönelik Eleştiri$l e r^{\prime \prime}$ teması altında ulaşılan sonuçlar tez yazılmamasının eksikliği, alan kısıtlaması olmaması, öğrenci alım koşullarının haksız rekabeti sağlaması ve alan dışı öğrencilere bilimsel hazırlık olmaması görüşleridir. Tez yazılmamasının eksikliği görüşü de ortaya çıkmıştır. Öğrenci alımında alan kısıtlaması olmaması fikrine katılımın çoğunlukta olduğu gözlenmiştir.

Birinci temayla ilgili tabloda yer verilen son kod olan alan dışı öğrencilere bilimsel hazırlık olmaması konusunun önemini vurgulamışlardır. İkinci tema ise eğitim kalitesi, niteliği, bölüm dersleri ve öğrenciyle ilgili etmenlerden ziyade eğitimcilerin etkisi de göz önünde bulundurularak oluşturulmuştur. Bulgular ışığında "Eğitim veren akademisyenler" temasıyla ilgili olarak reh-

Tablo 2. Madde 23 İlişkin Görüşlerin Çözümlenmesi

\begin{tabular}{|c|c|c|c|c|c|c|c|c|c|c|c|c|c|c|c|c|c|c|}
\hline \multirow[b]{2}{*}{ Tema } & \multirow[b]{2}{*}{ Kod } & \multicolumn{5}{|c|}{ Öğrenciler } & \multicolumn{5}{|c|}{ Akademisyenler } & \multicolumn{7}{|c|}{ Turist Rehberleri } \\
\hline & & 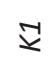 & $\underline{\underline{N}}$ & $\underline{m}$ & $\underset{\Sigma}{ }$ & $\stackrel{\ln }{2} \quad \underline{v}$ & $\hat{x}$ & $\stackrel{\infty}{1}$ & Q & 곰 & $\vec{\nabla}$ & $\underset{\nabla}{Z}$ & $\stackrel{n}{\ddot{Z}}$ & $\underset{\nabla}{Z}$ & $\stackrel{\operatorname{Ln}}{\tilde{\nabla}}$ & $\begin{array}{l}\sigma \\
\ddot{v}\end{array}$ & $\hat{\nabla}$ & $\stackrel{*}{z}$ \\
\hline \multirow{6}{*}{ 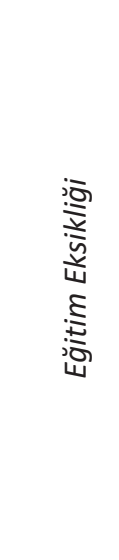 } & Teorik ders eksikliği & $x$ & $x$ & $x$ & $x$ & & $x$ & $x$ & & $x$ & $x$ & & & $x$ & $x$ & & $x$ & 11 \\
\hline & $\begin{array}{l}\text { Uygulamalı ders } \\
\text { eksikliği }\end{array}$ & $x$ & $x$ & $x$ & $x$ & & & $x$ & & $x$ & & & & $\mathrm{x}$ & $x$ & & $\mathrm{x}$ & 9 \\
\hline & $\begin{array}{l}\text { Eğitim temelinin zayıf } \\
\text { olması }\end{array}$ & $x$ & & $x$ & & & & & & & $x$ & & & $\mathrm{x}$ & $x$ & & & 5 \\
\hline & Uzmanlaşma eksikliği & & & & & & $x$ & & & & & & $x$ & $x$ & $x$ & & $x$ & 5 \\
\hline & $\begin{array}{l}\text { Multidisipliner bakış } \\
\text { açısına sahip } \\
\text { olamama }\end{array}$ & & & & $\mathrm{x}$ & & & & & & & & & $\mathrm{x}$ & & & $x$ & 3 \\
\hline & $\begin{array}{l}\text { Turizm disiplinine } \\
\text { hakim olmama }\end{array}$ & & & & & & $x$ & & & & & & & & & & & 1 \\
\hline \multirow{3}{*}{ 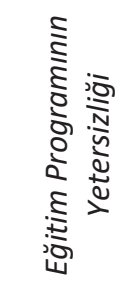 } & $\begin{array}{l}\text { Eğitim programının } \\
\text { yetersiz kalması }\end{array}$ & & & & $\mathrm{x}$ & $x$ & $x$ & $x$ & $x$ & $x$ & $x$ & & & & $\mathrm{x}$ & & & 8 \\
\hline & $\begin{array}{l}\text { Eğitim süresinin kısa } \\
\text { olması }\end{array}$ & & & & & $x$ & & & & $x$ & $x$ & & & & & $x$ & & 4 \\
\hline & $\begin{array}{l}\text { Eğitim seviyelerinin } \\
\text { farklı olması }\end{array}$ & $x$ & & & & & & & & & & & $x$ & & $x$ & & $x$ & 4 \\
\hline
\end{tabular}


Tablo 2. Madde 23 İlişkin Görüşlerin Çözümlenmesi (Devam)

\begin{tabular}{|c|c|c|c|c|c|c|c|c|c|c|c|c|c|c|c|c|c|c|c|}
\hline \multirow[b]{2}{*}{ Tema } & \multirow[b]{2}{*}{ Kod } & \multicolumn{6}{|c|}{ Öğrenciler } & \multicolumn{6}{|c|}{ Akademisyenler } & \multicolumn{6}{|c|}{ Turist Rehberleri } \\
\hline & & $\bar{\nabla}$ & $\underset{2}{2}$ & $\underline{n}$ & 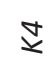 & 里 & $\ddot{v}$ & $\hat{\mathbf{v}}$ & $\stackrel{\infty}{\stackrel{\infty}{\nu}}$ & g) & $\underset{⿱ 亠 乂}{\stackrel{i}{x}}$ & $\underset{\forall}{Z}$ & $\underset{\nabla}{\underset{\nabla}{*}}$ & $\underset{\nabla}{\ddot{Z}}$ & $\underset{⿱ 亠 乂}{\Delta}$ & $\underset{⿱ 亠 䒑}{\underline{\Sigma}}$ & $\begin{array}{l}\sigma \\
\vec{\nabla}\end{array}$ & $\underset{\forall}{\vec{z}}$ & $\stackrel{*}{z}$ \\
\hline \multirow{4}{*}{ 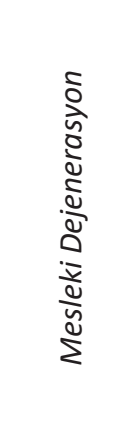 } & $\begin{array}{l}\text { Meslek imajına zarar } \\
\text { vermesi }\end{array}$ & $x$ & & & & & & & & $x$ & $x$ & & & & & & $x$ & & 4 \\
\hline & $\begin{array}{l}\text { Ülke imajına zarar } \\
\text { veren donanımsız } \\
\text { rehberlerin }\end{array}$ & $x$ & & & & & & & & & & & & & & & $x$ & & 2 \\
\hline & $\begin{array}{l}\text { Mesleğin ek iş olarak } \\
\text { görülmesi }\end{array}$ & & & & & $x$ & & & & & $x$ & & & & & & & & 2 \\
\hline & $\begin{array}{l}\text { Mesleki etiğe } \\
\text { uygunsuzluk }\end{array}$ & $x$ & & & & & & & & & & & & & & & & & 1 \\
\hline \multirow{2}{*}{ 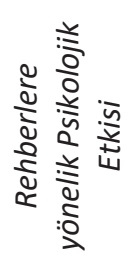 } & $\begin{array}{l}\text { Mevcut rehberler için } \\
\text { motivasyon düşürücü } \\
\text { etkisi }\end{array}$ & $x$ & $x$ & $x$ & $x$ & $x$ & & $x$ & $x$ & & $x$ & $x$ & $x$ & & & & & & 10 \\
\hline & $\begin{array}{l}\text { Meslek aidiyet } \\
\text { duygusunun } \\
\text { gelişmemesi }\end{array}$ & & $x$ & & & $x$ & & & & & $x$ & & & & & & & & 4 \\
\hline \multirow{6}{*}{ 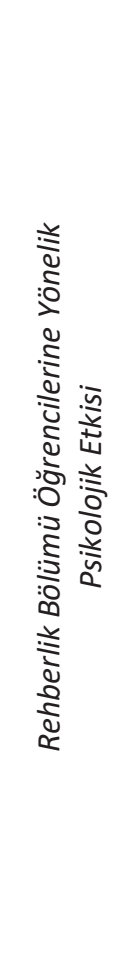 } & $\begin{array}{l}\text { Mevcut öğrencilerin } \\
\text { motivasyonunun } \\
\text { kırılması }\end{array}$ & $x$ & & $x$ & $x$ & $x$ & & & & $x$ & $x$ & $x$ & $x$ & & $x$ & & $x$ & & 10 \\
\hline & $\begin{array}{l}\text { Rehberlik } \\
\text { öğrencilerinin } \\
\text { mesleğe yönelik } \\
\text { güvenini kaybetmesi }\end{array}$ & & & & $x$ & & & & $x$ & & $x$ & & & & & & & & 3 \\
\hline & $\begin{array}{l}\text { Eğitime yönelik } \\
\text { idealist bakış açısını } \\
\text { kaybetme }\end{array}$ & & & & $x$ & $x$ & & & & $x$ & & & & & & & & & 3 \\
\hline & $\begin{array}{l}\text { Rehberlik } \\
\text { öğrencilerinde } \\
\text { gelecek kaygısı } \\
\text { oluşması }\end{array}$ & & & & $x$ & & & & & $x$ & & & & & & & & & 2 \\
\hline & $\begin{array}{l}\text { Öğrencilerin özlük } \\
\text { haklarının gasp } \\
\text { edilmesi }\end{array}$ & $x$ & & & & & & & & & & & & & & & & & 1 \\
\hline & $\begin{array}{l}\text { Rehberlik } \\
\text { öğrencilerinin meslek } \\
\text { değiştirme eğilimini } \\
\text { artırması }\end{array}$ & & $x$ & & & & & & & & & & & & & & & & 1 \\
\hline
\end{tabular}


Tablo 2. Madde 23 İlişkin Görüşlerin Çözümlenmesi (Devam)

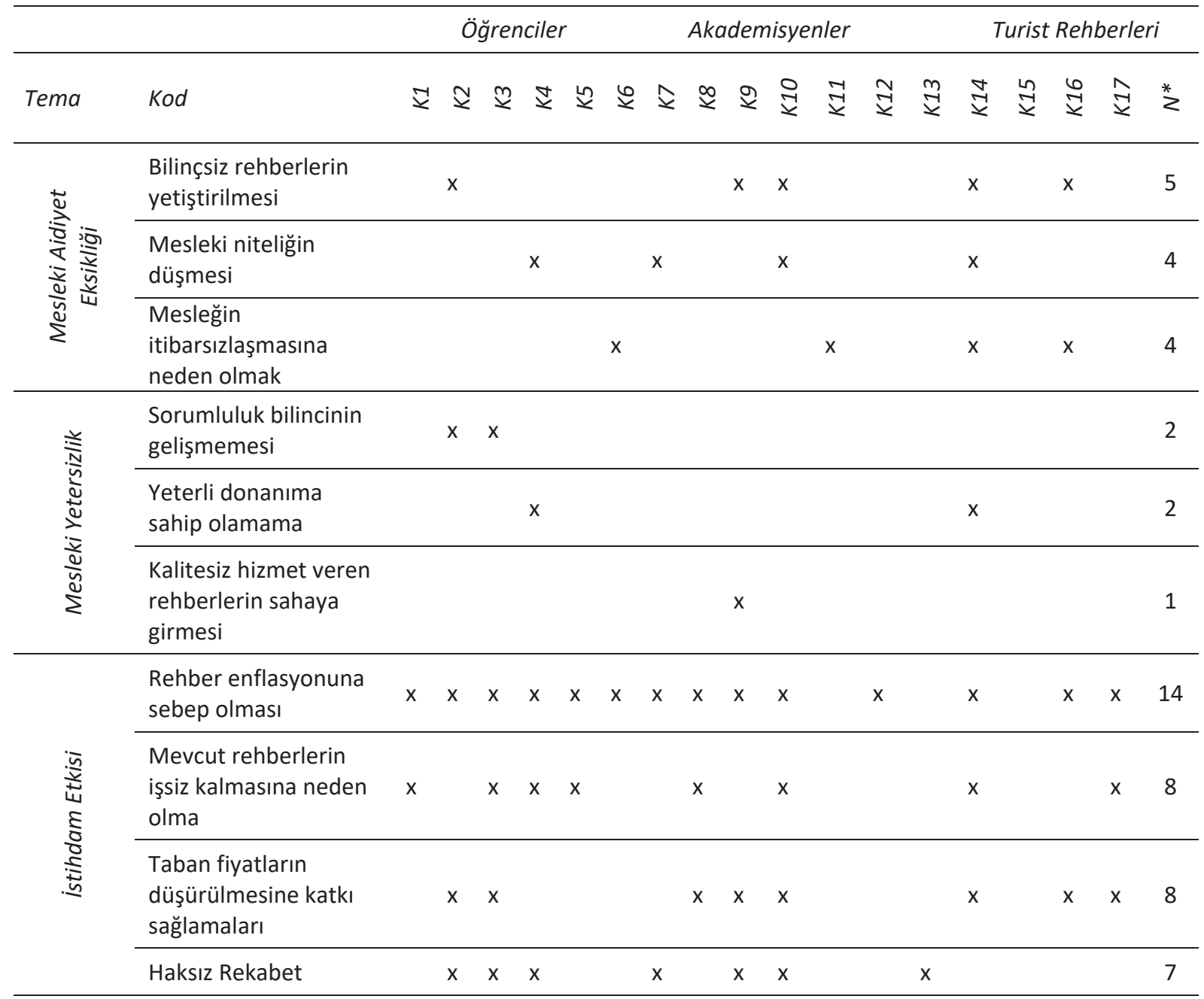

$\mathrm{N}$ : İadeye katılan kişi sayısını belirtmektedir.

berlik bölümü mezunu alan hocalarının eksikli$\breve{g} i$, sektörel deneyiminin olması gerekliliği ve son olarak alaninda uzman akademisyenlerin programı desteklemesi şeklinde alt kodlara ulaşılmıştır. Bu kodların oluşmasını sağlayan katılımcı ifade örneği aşağıda verilmiştir:

\footnotetext{
“Özellikle başka bir anabilim dalından gelenler için en az bir yıl bilimsel hazırlık olması gerekir. Turizm ile ilgili temel kavramlarında verildiği bir girişin olması, rehber adaylarının sektörün özellikleri ile ilgili bilgi sahibi olmasını sağlayacaktır." K6
}

Eğitime yönelik bulgular incelendiğinde " $E \breve{g} i-$ tim Programı Müfredatı" bir tema olarak ortaya çıkmıştır. Katılımcıların ifadeleri sonucunda lisansüstü eğitiminin amacının sadece rehber yetişmek olmadığı, aksine öğrencilere bilimsel araştırma yapma kabiliyeti ve yetisi kazandırmak olduğunun altı çizilmiştir. Lisansüstü eğitimin bilimsel teori ve uygulamalara yönelik verilmesi, lisansüstü eğitimle öğrencilere araştırma yapma yetisi kazandırılması, araştırma yöntemleri derslerinin artırılması, rehber yetiştirmekten önce uzmanlaşma derslerinin önceliğin gerekliliği, lisansüstü derslerin rehber yetiştirme hususunda lisans programı içerik olarak yetersiz olması, lisansüstü derslerin sayı olarak yetersiz 
Tablo 3. Lisansüstü Turizm Rehberliği Eğitimine İlişkin Görüşler

\begin{tabular}{|c|c|c|c|c|c|c|c|c|c|c|c|c|c|c|c|c|c|c|c|}
\hline \multirow[b]{2}{*}{ Tema } & \multirow[b]{2}{*}{ Kod } & \multicolumn{5}{|c|}{ Öğrenciler } & \multicolumn{8}{|c|}{ Akademisyenler } & \multicolumn{5}{|c|}{ Turist Rehberleri } \\
\hline & & $\vec{x}$ & $\underset{\Sigma}{\searrow}$ & $\underline{m}$ & $\underset{Z}{\mathbb{Z}}$ & $\stackrel{\text { № }}{\underline{n}}$ & $\ddot{v}$ & $\hat{z}$ & $\stackrel{\infty}{\longleftarrow}$ & Q & 올 & $\underset{\Sigma}{Z}$ & $\underset{\nabla}{*}$ & $\underset{\Sigma}{n}$ & $\underset{\Sigma}{\mathbb{Z}}$ & 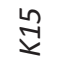 & $\begin{array}{l}\underset{v}{*} \\
\ddot{z}\end{array}$ & $\hat{\nabla}$ & $\stackrel{*}{z}$ \\
\hline \multirow{4}{*}{ 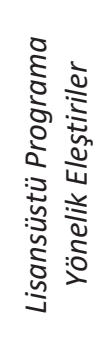 } & Alan kısıtlaması olmaması & & & & $x$ & & & $x$ & $x$ & $x$ & $x$ & $x$ & $x$ & & $x$ & & $x$ & $x$ & 10 \\
\hline & $\begin{array}{l}\text { Tezsiz YL'da Tez } \\
\text { yazılmaması }\end{array}$ & & & $x$ & & & & & & & & & & & $\mathrm{x}$ & $x$ & $\mathrm{x}$ & $x$ & 5 \\
\hline & $\begin{array}{l}\text { Alan dışı öğrencilere } \\
\text { bilimsel hazırlık olmaması }\end{array}$ & & & & & & $\mathrm{x}$ & & & & $\mathrm{x}$ & & & $\mathrm{x}$ & & & $\mathrm{x}$ & & 4 \\
\hline & $\begin{array}{l}\text { Öğrenci alım koşullarının } \\
\text { haksız rekabeti sağlaması }\end{array}$ & & & & & & $x$ & & $\mathrm{x}$ & & $\mathrm{x}$ & & & & & & & & 3 \\
\hline \multirow{3}{*}{ 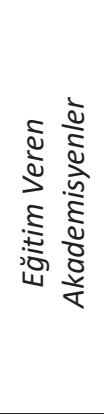 } & $\begin{array}{l}\text { Alanında uzman } \\
\text { akademisyenlerin } \\
\text { programı desteklenmesi } \\
\text { gerekliliği }\end{array}$ & & & $x$ & & & & $\mathrm{x}$ & & $x$ & & $x$ & & $x$ & & & $x$ & $x$ & 7 \\
\hline & $\begin{array}{l}\text { Sektörel deneyiminin } \\
\text { olması gerekliliği }\end{array}$ & & & $\mathrm{x}$ & $\mathrm{x}$ & & $\mathrm{x}$ & & & $x$ & $\mathrm{x}$ & & & & $\mathrm{x}$ & & & & 6 \\
\hline & $\begin{array}{l}\text { Rehberlik bölümü } \\
\text { mezunu alan hocalarının } \\
\text { eksikliği }\end{array}$ & & & $\mathrm{x}$ & & & & $x$ & $\mathrm{x}$ & $x$ & $x$ & & & & & & & & 5 \\
\hline \multirow{6}{*}{ 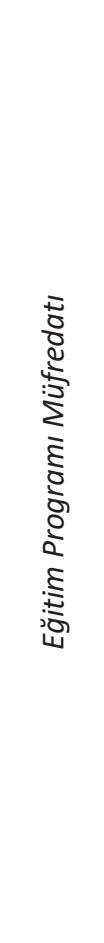 } & $\begin{array}{l}\text { Rehber yetiştirmekten } \\
\text { önce uzmanlaşma } \\
\text { derslerinin önceliğin } \\
\text { gerekliliği }\end{array}$ & & & $\mathrm{x}$ & & & & & & & & & & & $x$ & $\mathrm{x}$ & $x$ & $\mathrm{x}$ & 5 \\
\hline & $\begin{array}{l}\text { Lisansüstü eğitimin } \\
\text { bilimsel teori ve } \\
\text { uygulamalara yönelik } \\
\text { verilmesi }\end{array}$ & & & $x$ & & & & & & & & & & & & $x$ & $x$ & $\mathrm{x}$ & 4 \\
\hline & $\begin{array}{l}\text { Lisansüstü derslerin, } \\
\text { rehber yetiştirme } \\
\text { hususunda lisans } \\
\text { programı içerik olarak } \\
\text { yetersiz olması }\end{array}$ & & & & $x$ & & $x$ & & & & & & & & & & & & 2 \\
\hline & $\begin{array}{l}\text { Lisansüstü eğitimle } \\
\text { öğrencilere araştırma } \\
\text { yapma yetisi } \\
\text { kazandırılması }\end{array}$ & & & & $x$ & & & $x$ & & & & & & & & & & & 2 \\
\hline & $\begin{array}{l}\text { Araştırma yöntemleri } \\
\text { derslerinin artırılması }\end{array}$ & & & & & & & $x$ & & & & & & & & & & & 1 \\
\hline & $\begin{array}{l}\text { Lisansüstü derslerin sayı } \\
\text { olarak yetersiz olması }\end{array}$ & & & & & & $x$ & & & & & & & & & & & & 1 \\
\hline
\end{tabular}

olması kodları içerik olarak bu tema altında toplanmıştır. Aşağıda yer verilen katılımcı ifadeleri bu boyuta ilişkin örnek olarak sunulabilir: “...derslerin büyük bir çoğunluğu öğrenciyi akademiye hazırlar. Halbuki, TR lisans programı öğrenciye rehberlik için gerekli nitelikleri ve donanımları sağlamaktadır." K3 
Tablo 4. Lisansüstü Eğitimin İyileştirilmesine Yönelik Görüşler

\begin{tabular}{|c|c|c|c|c|c|c|c|c|c|c|c|c|c|c|c|c|c|c|c|}
\hline \multirow[b]{2}{*}{ Tema } & \multirow[b]{2}{*}{ Kod } & \multicolumn{5}{|c|}{ Öğrenciler } & \multicolumn{8}{|c|}{ Akademisyenler } & \multicolumn{5}{|c|}{ Turist Rehberleri } \\
\hline & & $\underline{z}$ & $\underline{\mathbb{N}}$ & $\stackrel{m}{2}$ & 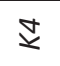 & $\underline{\underline{n}}$ & $\underline{6}$ & $\hat{z}$ & $\stackrel{\infty}{\sim}$ & शి & 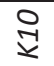 & $\underset{\nabla}{-}$ & $\underset{\nabla}{\sim}$ & $\underset{⿱ 乛}{\stackrel{n}{*}}$ & $\underset{\nabla}{\nabla}$ & $\underset{⿱ n}{\stackrel{n}{x}}$ & 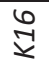 & $\vec{\nabla}$ & ${ }^{*} z$ \\
\hline \multirow{8}{*}{ 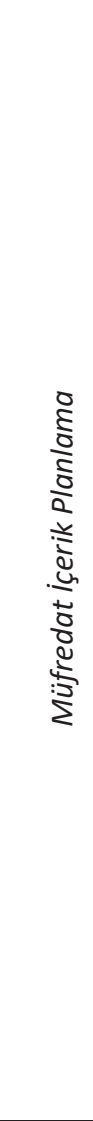 } & $\begin{array}{l}\text { Uzmanlaşma derslerinin } \\
\text { eklenmesi }\end{array}$ & & & $x$ & $x$ & & $x$ & & & & & & & $x$ & & $x$ & $x$ & $x$ & 7 \\
\hline & $\begin{array}{l}\text { Temel mesleki derslerin } \\
\text { yoğunlaştırılması }\end{array}$ & & & & & & & $\mathrm{x}$ & & & & & $\mathrm{x}$ & $x$ & & $x$ & $x$ & & 5 \\
\hline & $\begin{array}{l}\text { Tezli ve tezsiz lisansüstü } \\
\text { çıktılarının iyi } \\
\text { belirlenmesi ve } \\
\text { ayrıştırılması }\end{array}$ & & & & & & $x$ & & & & & $\mathrm{x}$ & $\mathrm{x}$ & & & $\mathrm{x}$ & $\mathrm{x}$ & & 5 \\
\hline & $\begin{array}{l}\text { Ders içerikleri dış } \\
\text { paydaşlar ile belirlenmesi }\end{array}$ & & & & & & $x$ & & $x$ & & & & & & & & & & 2 \\
\hline & $\begin{array}{l}\text { Ders içeriklerinin sektör } \\
\text { ihtiyacına göre } \\
\text { planlanması }\end{array}$ & & & & & & $\mathrm{x}$ & & & & & & $\mathrm{x}$ & & & & & & 2 \\
\hline & $\begin{array}{l}\text { Tezsiz programda } 6 \text { aylık } \\
\text { sertifika kursların ders } \\
\text { içerikleri baz alınma } \\
\text { gerekliliği }\end{array}$ & & & & $x$ & & & & & & & $x$ & & & & & & & 2 \\
\hline & $\begin{array}{l}\text { Temel Lisansüstü dersleri } \\
\text { üniversiteler arası ortak } \\
\text { bir toplantı ile } \\
\text { belirlenmeli }\end{array}$ & & & & & & & & & & $\mathrm{x}$ & & & & & & & & 1 \\
\hline & $\begin{array}{l}\text { Araştırma yöntemleri ve } \\
\text { istatistik derslerine de } \\
\text { ağırlık verilmesi }\end{array}$ & & & & & & & $x$ & & & & & & & & & & & 1 \\
\hline \multirow{6}{*}{ 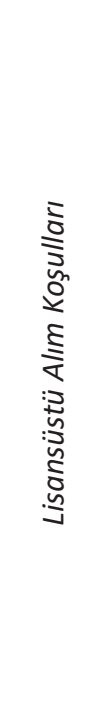 } & Alan kısıtlaması gerekliliği & & $x$ & & & & & & $x$ & $x$ & $x$ & & $x$ & & & $x$ & $x$ & & 7 \\
\hline & $\begin{array}{l}\text { Dil giriş puanının } \\
\text { yönetmeliğe göre } \\
\text { ayarlanması (75/C) }\end{array}$ & & & & & & $x$ & & & & $x$ & $x$ & $x$ & $\mathrm{x}$ & $x$ & & & $\mathrm{x}$ & 7 \\
\hline & $\begin{array}{l}\text { Turizm rehberliği bölümü } \\
\text { mezunlarının alınması }\end{array}$ & & & & & & & $x$ & $\mathrm{x}$ & $\mathrm{x}$ & $x$ & & & & $x$ & & & $x$ & 6 \\
\hline & $\begin{array}{l}\text { Rehberlik lisansı } \\
\text { derecesine sahip olan } \\
\text { akademisyenlerin } \\
\text { artırılması }\end{array}$ & & & & & & & $x$ & $x$ & & $x$ & & & $x$ & & & & & 4 \\
\hline & $\begin{array}{l}\text { Alan dışı için bilimsel } \\
\text { hazırlık şartı getirilmesi }\end{array}$ & & & & & & $x$ & & & & $x$ & & & $x$ & & & $x$ & & 4 \\
\hline & $\begin{array}{l}\text { Alan dışına açılımın } \\
\text { yalnızca nadir dillerde } \\
\text { olması }\end{array}$ & & & & & & $x$ & & & & & & $x$ & & $x$ & & & $x$ & 4 \\
\hline
\end{tabular}


Tablo 4. Lisansüstü Eğitimin İyileştirilmesine Yönelik Görüşler (Devam)

\begin{tabular}{|c|c|c|c|c|c|c|c|c|c|c|c|c|c|c|c|c|c|c|c|}
\hline \multirow[b]{2}{*}{ Tema } & \multirow[b]{2}{*}{ Kod } & \multicolumn{5}{|c|}{ Öğrenciler } & \multicolumn{8}{|c|}{ Akademisyenler } & \multicolumn{5}{|c|}{ Turist Rehberleri } \\
\hline & & $\vec{z}$ & $\underline{\Sigma}$ & $\underline{m}$ & 文 & $\underline{\underline{n}}$ & $\ddot{v}$ & $\underline{\underline{z}}$ & $\stackrel{\infty}{\sim}$ & D2 & 곰 & $\underset{\nabla}{Z}$ & $\underset{\nabla}{\nabla}$ & $\underset{\nabla}{\tilde{Z}}$ & $\underset{\nabla}{\nabla}$ & $\begin{array}{l}\tilde{L} \\
\vec{\nabla}\end{array}$ & $\begin{array}{l}\mathscr{V} \\
\vec{\nabla}\end{array}$ & $\vec{\nabla}$ & ${ }^{*} z$ \\
\hline \multirow{7}{*}{ 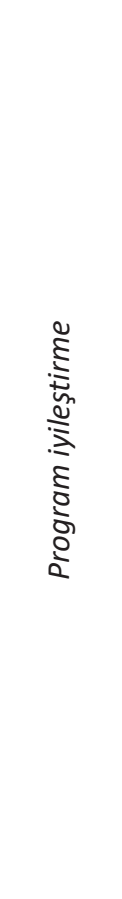 } & $\begin{array}{l}\text { Turizm Fakültesi } \\
\text { bölümlerine açılması }\end{array}$ & & & & & & & & & & $x$ & & & $x$ & & & & & 2 \\
\hline & $\begin{array}{l}\text { Uygulamalı derslerin } \\
\text { artırılması }\end{array}$ & & & & & & & & & $x$ & & & & & & $x$ & & & 2 \\
\hline & $\begin{array}{l}\text { Uluslararası ülkelerin iyi } \\
\text { uygulamalarının takip } \\
\text { edilmesi }\end{array}$ & & & & & & $x$ & & & & & & & & & & & & 1 \\
\hline & $\begin{array}{l}\text { Program isimlerinin } \\
\text { standartlaştırılması }\end{array}$ & & & & & $x$ & & & & & & & & & & & & & 1 \\
\hline & $\begin{array}{l}\text { Rehberlik alanında } \\
\text { çalışması olan } \\
\text { akademisyenlerin ders } \\
\text { vermesi }\end{array}$ & & & & & & & & & $x$ & & & & & & & & & 1 \\
\hline & $\begin{array}{l}\text { Turizm rehberliği } \\
\text { doktorası ile lisans } \\
\text { mezunlarının akademiye } \\
\text { yönlendirilmesi }\end{array}$ & & & & & & & & $x$ & & & & & & & & & & 1 \\
\hline & $\begin{array}{l}\text { Kontenjanların ihtiyaca } \\
\text { göre planlanması }\end{array}$ & & & & & & $x$ & & & & & & & & & & & & 1 \\
\hline \multirow{2}{*}{ 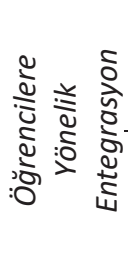 } & $\begin{array}{l}\text { Alan dışı öğrencilerin } \\
\text { turizm disiplinini } \\
\text { öğrenmelerini sağlama }\end{array}$ & & $x$ & $x$ & & & & & & & & & & & & & & & 2 \\
\hline & $\begin{array}{l}\text { Mevcut rehberlik } \\
\text { öğrencilerinin } \\
\text { özgüvenlerinin artırılması }\end{array}$ & & & & & & $x$ & & & & & & & & & & & & 1 \\
\hline
\end{tabular}

"Verilen derslerin sayı ve içerik olarak yetersiz olduğunu düşünüyorum." K6

Alt Problem 3'e Yönelik Çözümleme: Lisansüstü eğitimi iyileştirmeye yönelik görüşler kapsamda dört temaya ulaşılmıştır (Tablo 4). Bu dört temanın altında, 22 alt kod yer almaktadır. Bu tema ve alt kodlar detaylandırılırsa ilk tema başlığı "Müfredat İçrik Planlama" olmuştur. Lisansüstü eğitimde müfredatı ve içerik planlamasını iyileştirmek amacı taşıyan alt kodlar şunlardır: ders içerikleri diş paydaşlar ile belirlenmesi, ders içeriklerinin sektör ihtiyacına göre planlanması, uzmanlaşma derslerinin eklenmesi, tezli ve tezsiz lisansüstü çıktılarının iyi belirlenmesi ve ayrıştırılması, temel mesleki derslerin yoğunlaştırılma-
S1, araştırma yöntemleri ve istatistik derslerine de ağırlık verilmesi, temel lisansüstü dersler bir şura ile belirlenmeli, tezsiz programda altı aylık sertifika kursların ders içerikleri baz alınma gerekliliği. Bahsedilen alt kodlarda en fazla hemfikir olunan kod ise "uzmanlaşma derslerinin eklenmesi" olmuştur.

Lisansüstü eğitim müfredatına yönelik görüşler bildirilmiştir. Aslında müfredatın tamamen pürüzsüz bir eğitim sağlamasının bile iyileştiremeyeceği fakat müfredat içerik planlamasının iyileştirilmesi kadar da önemli olan bir husus daha belirlenmiştir. Bu husus ise "Lisansüstü Alım Koşulları" temasını oluşturmuştur. Bu temanın alt kodları ise: Alan kısıtlaması gerekliliği, turizm rehberliği bölümü mezunlarının alınması, 
turizm fakültesi bölümlerine açılması, alan dışı için bilimsel hazırlık şartı getirilmesi, alan dışına açılımın yalnızca nadir dillerde olmasıdır. Bahsedilen alt kodlarda en fazla hemfikir olunan iki konu vardır. Bunlardan birisi "turizm rehberliği bölümü mezunlarının alınması" ve "alan kısıtlaması gerekliliği" kodları olmuştur. Aşağıda, söz konusu bulgu bağlamında bir örnek verilmiştir:

\begin{abstract}
"Çıkış noktasının mantıklı olup uygulamada üniversiteler tarafından amacına uygun olarak kullanılmayan bir durum oluşmasına sebebiyet vermiştir. Tezsiz yüksek lisans, bakanlık kurslarının iptal edilip rehberlik alanında lisans - ön lisans mezunu olmayıp farklı alanlarda lisans eğitimi görmüş ve özellikle nadir dillere sahip bireylerin turist rehberi olmasını sağlayan bir uygulamadır. En azından bu amaçla getirilmiş bir uygulamadır. Fakat bakanlık kursları kapanmadığı gibi tezsiz yüksek lisans uygulaması da nadir dillere hizmet etmeyecek şekilde üniversitelere açılmıştır. Kimi üniversiteler asgari dil şartı ile öğrenci alma yoluna gitmiştir. Üçüncü Turizm şurasında da ileriki turizm planlamasında tezsiz eğitime son verilmesine yönelik kararlar alınmıştır. Ayrıca İstanbul Rehberler Odası 2018 yılında tezsiz rehberlik eğitiminin son derece şikayetlere sebep olduğu ve amacına uygun şekilde işlemediğine yönelik bir basın duyurusu da yayınlamıştır. Öte yandan bu programları açma hususunda üniversitelerde bir kıstas olmaması da büyük bir yanlış. Örneğin X üniversitesinde turist rehberliği bölümü yok, fakültede bir adet turist rehberi olan ya da turist rehberliği bölümü mezunu hoca yok ama tezsiz turist rehberliği programı var. Şimdi bu bölgede bir turist rehberi ihtiyacı var mıdır? Yüksek lisans seviyesinde eğitim gören bu öğrencilere kim nasıl hangi rehberlik eğitimini vermektedir?" K12
\end{abstract}

Müfredattaki ve alım koşullarındaki iyileştirmeleri sağlamak için program iyileştirmesi de gerekli görülmüştür. "Program iyileştirme" tema başlı̆̆1 eklenerek birbirinden önemli yedi alt kod ortaya çıkmıştır. Bu kodlar: Program isimlerinin standartlaştırılması, kontenjanların ihtiyaca göre planlanması, uluslararası ülkelerin iyi uygulamalarının takip edilmesi, rehberlik lisansı derecesine sahip olan akademisyenlerin artırılması, rehberlik alanında çalışması olan akademisyenlerin ders vermesi, turizm rehberliği doktorası ile lisans mezunlarının akademiye yönlendirilmesi, uygulamalı derslerin artırılması. Alt kodlar incelendiğinde ise "rehberlik lisansı derecesine sahip olan akademisyenlerin artırılması" kodu katılımc1ların çoğunun dile getirdiği görüşler içerisinde yer almıştır.
Son olarak "öğrencilere yönelik entegrasyon" teması ele alınmıştır ve iki alt kod oluşturulmuştur. Bu alt kodlar ise: Alan dişı öğrencilerin turizm disiplinini öğrenmelerini sağlama ile mevcut rehberlik öğrencilerinin özgüvenlerinin artırılmasıdır. Görüldügü üzere her tabloda yer verilen psikolojik etkiler Madde 23'e bakış açısının beraberinde getirdiği olumsuzlukları ortadan kaldırmak, lisansüstü eğitim görüşleri, lisans ve lisansüstü eğitimi iyileştirmek adına gereklidir.

\section{SONUÇ VE ÖNERILER}

Bireylerin bir meslekte uygulamaya geçmesi için belirli bir eğitim düzeyini tamamlaması gerekmektedir (Tanrısever 2019). Bu araştırmaya söz konusu araştırma problemi Yönetmelik'te yer alan lisansüstü eğitimler Tanrısever'in (2019) vurguladığ 1 bu gereklilikten yola çıkan bir bakış açısı ile oluşturulmuştur. Çalışmada yapılan çözümlemeler ile Madde 23'ün kısıtlarının makro boyutlu olduğu görülmüştür. Bu temel boyutlar "eğitim eksikliği, eğitim programının yetersiz oluşu, mesleki dejenerasyon, rehberlere ve öğrencilere yönelik psikolojik etki, mesleki aidiyet eksikliği, mesleki yetersizlik ve istihdam etkisi" olarak ortaya çıkmıştır. Bu içerikler arasında mesleki aidiyet eksikliği önemli bir sonuç olarak ortaya çıkmaktadır. Çünkü mesleki aidiyetin yüksek olması turistlerin turlardan olumlu tecrübeler edinmesine kapı açacaktır. Madde 23 sayesinde sektöre daha fazla rehber kazand1rılmasının sonuçlarından birisi ise mesleki aidiyet eksikliği olacaktır. Bunun sonucunda sektörde bilinçsiz rehberlerin olması ve mesleğin ek iş olarak görülmesine yol açacağı düşünülmüştür. Mesleği ek iş olarak icra eden turist rehberlerini tura çıkarmak mesleki bağlılık eksikliğine ve mesleğin önü kesilip umut veren bir gelecekten yoksun olmasina neden olacaktır (Mak vd. 2011).

Eğitim eksikliği bağlamında bir yıl araştırma yöntemleri odaklı ders aşaması ve bir yılda tez/ proje dönemi olarak eğitimin verildiği lisansüstü eğitimlerin içeriklerinin yetersiz olduğu görüşü ortaya çıkmıştır. Literatürde ülkenin tanıtımından destinasyonun ekonomik sürdürülebilirliğine kadar önemli konularda kritik görevler üstlenen rehberlerin, yetkinliği ve donanımı için teoriğin yanında, pratiğe ve uygulama konularını 
içeren iyi bir eğitimden geçmeleri gerektiği vurgulanmaktadır (Jacobson ve Robles 1992; Christie ve Mason 2003; Güzel vd. 2019). Özellikle teorik derslerin rehber yetiştirmeye yönelik olmadığı, yetersiz kaldığı, uygulamalı derslerin yetersiz oluşu en çok göze çarpan sonuçlar olmuştur. Yenipınar ve Zorkirişçi'nin (2013) Avrupa'daki turist rehberliği eğitim sürecinin uygulamadaki teknik çeşitliliği, uzmanlık kazandırma, yönlendirme ve teorik yanında pratiğin de eğitime aynı yoğunlukta dahil edilmesinin Türkiye'deki teorik ve pratik eğitim uygulamalarında yetersiz kaldığ keşfettiği çalışma lisans programlarının sorgulanmasını hedef alırken, Madde 23 ile birlikte lisansüstü eğitimlerde yeni sorgulanacak alanlar olarak ortaya çıkmıştır. Türkiye'de olduğu gibi Avustralya, Amerika, İngiltere ve Costa Rica gibi ülkelerde de eğitimin yanı sıra detaylı ve zengin içerikli eğitim sertifika programları ile rehberler yetiştirilmektedir (Jacobson ve Robles 1992; Knudson vd 1995; Mason ve Christie 2003; Rabotić 2015; Lovrentjev 2015).

İngiltere'de de turist rehberliği, eğitim yoluyla edinilen ve bir lisans gerektiren meslek olarak kabul edilmektedir. Başvuranların rehberlik konusunda temel bilgileri edindiği özel olarak düzenlenmiş kursların yanı sıra özel turist rehberliği bölümlerinde Türkiye, Mısır, Litvanya ve Malta gibi ülkelerde yapıldı ğı gibi 2-4 yıl süren eğitim ve üniversitelerin çalışma programları da mevcuttur (Rabotić 2015).

Araştırma sonuçlarına göre önlisans-lisans öğrencilerinin aldığı eğitim ile kıyaslandığında haksız bir rekabetin ortaya çıktığı gözlemlenmektedir. Nitekim "rehberlik bölümü öğrencileri ve turist rehberlerine yönelik psikolojik etkiler"e bakıldığında bu durumun her iki taraf içinde motivasyon düşürücü bir etki yarattığı sonucu ortaya çıkmaktadır. Özellikle öğrencilerin henüz eğitimleri esnasında mesleğe yönelik güvenlerini kaybetmeleri, özlük haklarının gasp edildiğini düşünmeleri, gelecek kaygisı taşımaları ve sektör değiştirme yoluna gitmeleri üzücü bir sonuç olarak ortaya çıkmıştır. Bu açıdan Yarcan'ın da (2017) belirttiği gibi farklı düzeyde eğitim almış rehberlerin varlığı, kalite farklılığ yaratacaktır.

Alan dışı lisansüstü öğrencilerin turizm reh- berliği hakkı edinerek rehber olmalarının getirdiği bir takım olumsuz sonuçlarda çıktı olarak bulgularda ortaya çıkmıştır. Eğitim programının yetersizliği ile kısa sürede kısıtlı dersleri alarak rehber olan kişilerin mesleki dejenerasyona sebep olabileceği ortaya çıkarken, donanımsız rehberler ile mesleğin imajının zedenelenebileceği, mesleğin ek iş olarak görülerek itibarsızlaştırılabileceği, etiğe uygun davranışları sergilemeyen rehberlerin sektörde çalışmaya başlayacağı vurgusu yapılmıştır. Eğitim programının yetersizliğine ek olarak tam donanıma sahip olmayan rehberlerin mesleki yetersizlik ile de karşılaşacakları aşikardır. Yine bu boyut, mesleki dejenerasyon boyutunu destekleyen bir unsur haline gelecektir. Nitekim kısıtlı eğitim ile sorumluluk bilincine ve yeterli donanıma sahip olmayan kişiler mesleği icra ederken, kalitesiz rehberlik hizmeti verilerek, ülke ve meslek imajına da olumsuz katkı sağlayacaktır. Rehberlik mesleğinde yüz yüze hizmet verildiği ve hizmet anlık gerçekleştiği için nitelikli bir hizmet sağlamak oldukça önemlidir. Bu açıdan Çetin ve Yarcan'ın da (2017) belirttiği gibi rehberlik eğitimi, rehber-tur operatörü ilişkisinde dikkate alınmalıdır.

Sektörde çalışan rehberler için ise istihdam boyutu ile ortaya çıkan sonuçlar düşündürücüdür. Özellikle kriz ortamlarından kolay etkilenen turizm sektöründe yeterli donanıma sahip olmayan kişilerin rehber olması ile birlikte rehber enflasyonu ortaya çıkarken, mevcut rehberlerin işsiz kalması sonucunun gözlemlenebileceği görüşü ortaya atılmıştır. Ayrıca yeterli donanıma sahip olmayan kişilerin yönetmelikte yasak olduğu ve disiplin suçu gerektiren taban altında tura çıkarak tur fiyatlarının düşürüleceğine ve bununda haksız rekabeti doğuracağı kaygısı katılımcılar tarafından vurgulanmıştır. Alanyazında konu ile ilişkili olan tek çalışma Çokişler' in (2017) tarafından gerçekleştirilmiş ve bu kaygılar da belirtilmiştir.

Yönetmeliğinde alan dışı öğrencilerin rehber olmasına olanak tanıdığı mevcut lisansüstü eğitimin durumunun değerlendirilmesi açısından yöneltilen soru ile de mevcut lisansüstü eğitimin durumu gözler önüne serilmiştir. Lisansüstü programına yönelik birtakım eleştiriler sunul- 
muştur. Bunlar alan kısıtlaması olmaması, tezsiz eğitimin bitirilmesi, bilimsel hazırlığın verilmemesi ve alım koşullarının haksız rekabeti sağlaması olarak ortaya çıkmıştır. Lisansüstü eğitim bağlamında eğitim veren akademisyenlerin özellikle sektörel deneyimi olan ve aynı lisans derecesine sahip olan öğretim üyeleri merkezli olması gerekliliği çıktı olarak ortaya çıkmıştır. Eğitim programı müfredatı boyutu ise en geniş içeriğe sahip olan boyut olarak belirlenmiştir. Bu içerik bağlamında ele alındığında lisansüstü eğitimin amacının, bilimsel araştırmalar yapma yeteneği donanımını inşa etmek olduğu, bu hususta eğitim programlarının sayı ve araştırma odaklı ders içeriği bağlamında eksik olduğu eleştirileri merkezli olduğu görülmüştür. Nitekim turist rehberi adaylarının derin bir tarih, mitoloji, flora-fauna, iklim, nüfus, genel kültür, coğrafya vb. konular ile ilgili donanımlı olması gerekmektedir $(\mathrm{Hu}$ 2007).

Araştırmanın temel hedeflerinden birisi de Madde 23'e eleştirel bir bakış açısı sağlarken, uygun çözüm fikirlerinin de üretilmesiydi. Bu bağlamda elde edilen bulgular mevcut uygulamaya katkı sağlayacak çözüm önerileri sunmuştur. Müfredatın planlanması aşamasında uzmanlaşma, araştırma ve temel mesleki derslerinin eklenmesi gerekliliği, derslerin belirlenmesi esnasında eğitim-öğretim süreci planlanması aşamasında sektörel ihtiyacın gözetilmesi gerekliliği, dış paydaşların fikirlerinin alınması gerekliliği, lisansüstü eğitimi veren tüm üniversitelerin iş birliği kapsamında toplantılar yaparak fikir birliğine varmaları gerekliliği gibi öneriler sunulmuştur. Yine alan dışı öğrencilerin lisansüstü turizm rehberliği eğitimine alınmaları bağlamında alım koşullarının yeniden revize edilmesi ise bir boyut olarak belirlenmiştir. Nitekim benzer öneri Çokişler'in (2017) çalışmasında da ortaya çıkmıştır. Bu boyut bağlamında ise alan kısıtlamasının getirilmesi gerekliliği, alan dışına açılmanın sorgulanması çok gerekli hallerde iyi planlanarak kabul edilmesi sonucu ortaya çıkmıştır. Yine bir diğer öneri boyutu ise program iyileştirme boyutu olarak elde edilmiştir. Bu bağlamda ise program isimlerinde birlik sağlanması, uluslararası iyi uygulamaların incelenmesi, turizm fakültesi bünyesindeki öğrencilerin programa dahil edilme- si, rehberlik alanında çalışmaları ve deneyimleri olan öğretim üyelerinin programları yürütmeleri, kontenjanın sektör ihtiyacına göre belirlenerek açılması gibi somut önerileri sunulmuştur. Ayr1ca özellikle bu programların açılmasında nadir dillerin gözetilmesi hedefi gözetildiği için öğrenci alımlarında Yönetmelikte belirlenen seviyede (75/C) dil şartının konulması önerilebilir. Örneğin bazı ülkelerin yapmış olduğu düzenlemeye göre öğrencilerin bazı temel yeterlilikleri taşıyor olmaları gerekmektedir. Örneğin, Avusturya'da turist rehberliği yeterlilik sınavı öngörülmektedir (Lovrentjev 2015). Alan dışı öğrencilerin ise lisansüstü eğitim entegrasyonu ile turizm disiplini kavramalarının sağlanması da bir öneri olarak ortaya çıkmıştır. Çokiş̧ler'in (2017) vurguladığ 1 gibi rehberlik eğitimi, herhangi bir dış etkenden etkilenmeyecek şekilde evrensel eğitim esaslarına dayandırılmalıdır. Bu önerilerin yanı sıra yazarlar, mevcut yönetmelik üzerindeki maddenin revize edilmesini önermektedirler.

\section{KAYNAKÇA}

Ar, H. (2015). Somut Olmayan Kültürel Mirasın Korunmasında Turist Rehberinin Rolü (Basılmamış Doktora Tezi). Balıkesir: Balıkesir Üniversitesi Sosyal Bilimler Enstitüsü.

Avcıkurt, C., Alper, B. ve Geyik, S. (2009). Education and Training of Tourist Guides in Turkey, Management and Education Academic Journal, 5 (1): 57-63.

Black, R. ve Weiler, B. (2005). Quality Assurance and Regulatory Mechanisms in the Tour Guiding Industry: A Systematic Review, Journal of Tourism Studies, 16 (1): 24.

Branislav, R. (2010). Tourist Guides in Contemporary Tourism. Saraybosna: International Conference on Tourism and Environment.

Cetin, G. ve Yarcan, S. (2017). The Professional Relationship Between Tour Guides and Tour Operators, Scandinavian Journal of Hospitality and Tourism, 17 (4): 345-357.

Christie, M. F. ve Mason, P. A. (2003). Transformative Tour Guiding: Training Tour Guides to Be Critically Reflective Practitioners, Journal of Ecotourism, 2 (1): 1-16.

Coccossis, H. (2005). Operational Management of Cultural and Heritage Sites. İçinde; International Cultural Tourism (ss. 73-85). Burlington: Elsevier Butterworth-Heinemann.

Cohen, E. (1985). The Tourist Guide: The Origins, Structure and Dynamics of a Role, Annals of Tourism Research, 12 (1): 5-29.

Creswell, J. W. (2016). Nitel Araştırma Yöntemleri: Beş Yaklaşıma Göre Nitel Araştırma ve Araştırma Deseni. İçinde; M. Bütün ve S. B. Demir (Çev. Editörler). Ankara: Siyasal Kitabevi. 
Çokişler, N. (2017). Turizm Rehberliği Eğitiminde Çeyrek Asırdır Değişmeyen Parçalanmış Yapı Sorunu, 3. Turizm Şürası Tebliğler Kitabı, 2: 325-335.

Değirmencioğlu, A. Ö. (2001). Türkiye'de Turizm Rehberliği Eğitimi Üzerine Bir Araştırma, Anatolia Turizm Araştırmaları Dergisi, 12 (2): 10-14.

Eker, N. ve Zengin, B. (2016). Turist Rehberliği Eğitiminin Değerlendirilmesi: Profesyonel Turist Rehberleri Üzerine Bir Uygulama, Ĕ̆itim ve Öğretim Araştırmaları Dergisi, 5 (4): 65-74

Güzel, F. Ö. ve Köroğlu, Ö. (2014). Turist Rehberlerinin Liderlik ve Aracılık Rollerinin Tur Deneyimine Etkisi: Doğa Turları Üzerine Bir Araştırma, Gaziantep University Journal of Social Sciences, 13 (4): 939-960.

Güzel, F.Ö., Kalin, V., Nacak, E. ve Bilgi, E. (2019). Turist Rehberi Adaylarının 2019 Yılı Eğitim Uygulama Gezisine Yönelik Algıları: Nitel Bir Araştırma, Türk Turizm Araştırmalar Dergisi, 3: 575-595.

Hu, W. (2007). Tour Guides and Sustainable Development: The Case of Hainan, China (Basılmamıs Doktora Tezi). Waterloo: Waterloo Üniversitesi.

Huang, S., Hsu, C. H. C. ve Chan, A. (2010). Tour Guide Performance and Tourist Satisfaction: A Study of the Package Tours in Shanghai, Journal of Hospitality and Tourism Research, 34 (1): 3-33.

Jacobson, S. K. ve Robles, R. (1992). Ecotourism, Sustainable Development, and Conservation Education: Development of a Tour Guide Training Program in Tortuguero, Costa Rica, Environmental Management, 16 (6): 701-713.

Kabii, F., Okello, M. M. ve Kipruto, N. (2017). Effects of Tour Guides Training on Their Performance in Kenya, Journal of Tourism and Hospitality Management, 5 (6): 233250.

Köroğlu, Ö. (2010). İş Doyumu ve Motivasyon Düzeylerini Etkileyen Faktörlerin Performansla İlişkisi: Turist Rehberleri Üzerine Bir Araștırma (Basılmamıs Doktora Tezi). Balıkesir: Balıkesir Üniversitesi Sosyal Bilimler Enstitüsü.

Knudson, D. M., Cable, T. T. ve Beck, L. (1995). Interpretation of Cultural and Natural Resources. PA: Venture Publishing, Cato Ave, State College.

Landis, J. R. ve Koch, G. G. (1977). The Measurement of Observer Agreement for Categorical Data, Bimetrics, 33: 159-174.

Lovrentjev, S. (2015). Education of Tourist Guides: Case of Croatia, Procedia Economics and Finance, 23: 555-562.
Mak, A. H., Wong, K. F. ve Chang, C. Y. (2011). Critical Issues Affecting the Service Quality and Professionalism of the Tour Guides in Hong Kong and Macau, Tourism Management, 32 (6): 1442-1452.

Mason, P. ve Christie, M. (2003). Tour Guides as Critically Reflective Practitioners: A Proposed Training Model, Tourism Recreation Research, 28 (1): 23-33.

Mayaka, M. ve Akama, J. S. (2007). Systems Approach to Tourism Training and Education: The Kenyan Case Study, Tourism Management, 28 (1): 298-306.

McDonnell, I, S. (2001). The Role of the Tour Guide in Transferring Cultural Understanding. Sydney: School of Leisure and Tourism Studies, University of Technology.

Polat, T. (2001). Seyahat İşletmelerinde Profesyonel Turist Rehberliği, Rehberlik Mesleğinin Sorunları ve Çözüm Önerileri Üzerine Bir Araștırma (Basılmamıș Yüksek Lisans Tezi). Eskişehir: Anadolu Üniversitesi, Sosyal Bilimler Enstitüsü.

Rabotić, B. (2010). Tourist Guides in Contemporary Tourism. International Conference on Tourism and Environment, Philip Noel-Baker University (ss. 353-364). 4-5 Mart 2010. Bosnia and Herzegovina: Sarajevo

Tanrısever, C., Bektaş, İ. ve Koç, E. D. (2019). Dünyada Turist Rehberliği Eğitimi, Turist Rehberliği Dergisi, 2 (1): 44-56.

Tsaur, S. H. ve Lin, W. R. (2014). Hassles of Tour Leaders, Tourism Management, 45: 28-38.

TÜREB (2020). Türkiye Rehberler Birliği, http://wwww.tureb.org. tr/tr/Page/Detail/60, (Erişim tarihi: 06.12.2020).

Wong, J. Y. ve Lee,W. H. (2012). Leadership Through Service: An Exploratory Study of the Leadership Styles of Tour Leaders, Tourism Management, 33 (5): 1112-1121.

Wong, J. Y. ve Wang, C.-H. (2009). Emotional Labor of the Tour Leaders: An Exploratory Study, Tourism Management, 30 (2): 249-259.

Yarcan, Ş. (2007). Profesyonel Turist Rehberliğinde Mesleki Etik Üzerine Kavramsal Bir Değerlendirme, Anatolia: Turizm Araştırmaları Dergisi, 18 (1): 33-44.

Yıldırım, A. ve Şimşek, H. (2013). Sosyal Bilimlerde Nitel Araştırma Yöntemleri. Ankara: Seçkin Yayıncılık.

Yenipınar, U. ve Zorkirişci, A. (2013). Türkiye ve Avrupa Birliği Ülkelerinde Turist Rehberliği Eğitimi, Cag University Journal of Social Sciences, 10 (2): 111-136. 


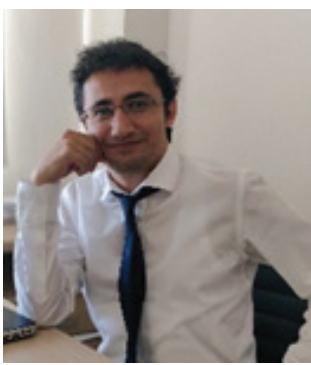

\section{Caner ÜNAL}

Anadolu Üniversitesi İ̧̧letme Fakültesi (Açıköğretim) İ̧̧letme Bölümü (2010) ve Adnan Menderes Üniversitesi Turizm Iş̧letmeciliği ve Otelcilik Yüksekokulu Seyahat İ̧̧letmeciliği ve Turizm Rehberliği Bölümü mezunudur (2011). Ceşitli seyahat acentelerinde turist rehberi olarak görev aldı. Yüksek lisans derecesini Akdeniz Üniversitesi'nden Turizm İşletmeciliği ve Otelcilik Anabilim Dalı'ndan (2015), doktora derecesini Akdeniz Üniversitesi Turizm İşletmeciliği Dalı’ndan aldı (2020). Antalya Bilim Üniversitesi'nde çalışmaya başladı (2017) ve halen doktor öğretim üyesi olarak görevine devam etmektedir. Temel çalışma alanları, turist rehberliği, turizm işletmeciliği, destinasyon yönetimi ve turizm pazarlamasıdır.

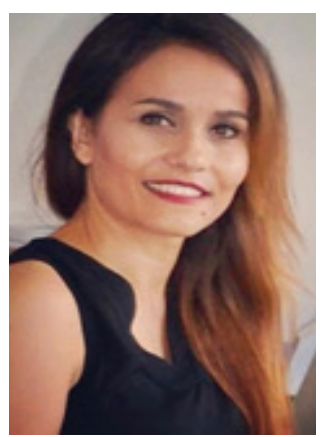

\section{Özlem GÜZEL}

Lisans derecesini Erciyes Üniversitesi, Nevşehir Turizm ve Otel İşletmeciliği Yüksekokulu, Turist Rehberliği bölümünde aldıktan sonra (2004), Balıkesir Üniversitesi, Turizm ve Otel İ̧̧letmeciliği Anabilim Dalı'nda yüksek lisansını tamamladı (2007). Incoming hizmeti veren seyahat acentelerin da turist rehberliği ve tur operasyonunda görev alarak sektör deneyimi edindikten sonra Muğla Sıtkı Koçman Üniversitesi Turizm ve Seyahat İşletmeciliği Bölümü’nde öğretim görevlisi olarak ders vermeye başladı (2007). Süleyman Demirel Üniversitesi, İşletme Anabilim Dalı'nda deneyim pazarlaması üzerine verdiği doktora teziyle doktorasını tamamladı (2012). Akdeniz Üniversitesi Turizm Fakültesi'nde öğretim üyesi olarak göreve başladı (2014). Doçent unvanı aldı (2016). Temel çalışma alanları; turist rehberliği çalışmaları, turizm pazarlaması, sürdürülebilir turizm ve inanç turizmidir.

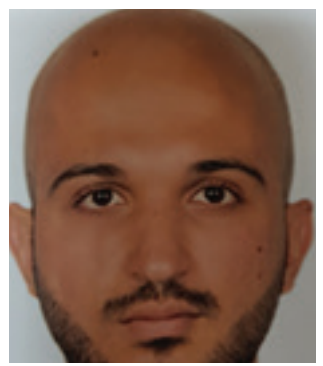

\section{Muhammedali YAŞAR}

Akdeniz Üniversitesi Turizm Fakültesi Turizm Rehberliği Bölümü’nden mezun oldu (2019). Akdeniz Üniversitesi Sosyal Bilimler Enstitüsü Turizm Rehberliği Anabilim Dalı'nda yüksek lisans yapmaktadır. Tez yazım aşamasındadır. Antalya TanTur\&TUi şirketinde çalıştı (2020). Temel çalışma alanları; inanç turizmi, şarap turizmi, kültürel miras ve Yunan mitolojisidir.

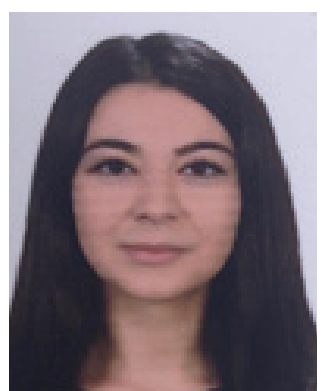

Fatma Nur KELEŞ

Aydın Adnan Menderes Üniversitesi Turizm Rehberliği Bölümü'nden mezun oldu (2020). Akdeniz Üniversitesi Sosyal Bilimler Enstitüsü Turizm Rehberliği alanında tezli yüksek lisans yapmaktadır (2020-2021). Temel çalışma alanları; Hristiyanlık tarihi ve sanatı, antik toplum tarihi ve sanatı, Roma ve Yunan mitolojisi, kültürel mirastır. 